\title{
Article
}

\section{Why Hitler Did Not Have Atomic Bombs}

\author{
Manfred Popp (1)
}

check for updates

Citation: Popp, M. Why Hitler Did Not Have Atomic Bombs. J. Nucl. Eng. 2021, 2, 9-27. https://doi.org/ $10.3390 /$ jne2010002

Received: 22 May 2020

Accepted: 31 December 2020

Published: 2 February 2021

Publisher's Note: MDPI stays neutral with regard to jurisdictional claims in published maps and institutional affiliations.

Copyright: (C) 2021 by the author. Licensee MDPI, Basel, Switzerland. This article is an open access article distributed under the terms and conditions of the Creative Commons Attribution (CC BY) license (https:// creativecommons.org/licenses/by/ $4.0 /)$.
Karlsruhe Institute of Technology, Weberstr. 5, D-76133 Karlsruhe, Germany; popp@kit.edu

\begin{abstract}
In the 75 years since the end of World War II there is still no agreement on the answer to the question of why the presumed race between the USA and Nazi-Germany to build the atomic bomb did not take place. New insights and answers are derived from a detailed analysis of the most important document on the subject, the official report of a German army ordnance dated February 1942. This authoritative document has so far not been adequately analyzed. It has been overlooked, particularly that the goal of the Uranium Project was the demonstration of a self-sustaining chain reaction as a precondition for any future work on power reactors and an atomic bomb. This paper explores why Werner Heisenberg and his colleagues did not meet this goal and what prevented a bomb development program. Further evidence is derived from the research reports of the Uranium Project and from the Farm Hall transcripts. Additional conclusions can be drawn from the omission of experiments, which could have been possible and would have been mandatory if the atomic bomb would have been the aim of the program. Special consideration is given to the role of Heisenberg in the Uranium Project.
\end{abstract}

Keywords: German uranium project; atomic bomb concepts; reactor experiments; US-German race for the atomic bomb; Werner Heisenberg

\section{Introduction}

Albert Einstein's fear that the national socialist regime in Germany would develop atomic bombs was the initial impetus for the Manhattan Project in the USA [1]. And indeed, only four months after Otto Hahn's discovery of nuclear fission, the German "Uranium Project" was launched in April 1939. Its failure makes it one of the few harmless chapters of the disastrous moral legacy of the Nazi-regime. It had no priority for German historians. The Allied victors, however, having to justify the development of the bombs dropped on Hiroshima and Nagasaki, wanted to find out why the presumed race against the German scientists had not occurred. Thus, this part of history became a domain of American and British historians. Surveys of their findings by the Dutch physicist Niclas P. Landsman [2] and the author [3] show that the interpretation of the documents by the various authors covers a surprisingly wide spectrum. For the last 30 years, however, the American historian Mark Walker has dominated the thinking about the Uranium Project. His conclusion is that the German physicists did not hesitate "to work on weapons of mass destruction for the Third Reich" [4].

This allegation is examined especially in the light of the official report of the Heereswaffenamt (army ordnance) of February 1942, the most important yet so far insufficiently examined document of the German Uranium Project. The focus on the first three years of the project is reasonable because only an early start would have allowed the national socialists regime to build atomic bombs in Germany.

\section{Would the Development of Atomic Bombs Have Been Possible in the "Third Reich"?}

Among the leading scientists of the Manhattan Project, many were German Jews who had been forced to leave the country because of the anti-Semitic legislation of the Nazi-regime: Hans Bethe, the head of weapon development, Edward Teller who later 
developed the thermonuclear bomb, Rudolf Peierls who solved the ignition problem of the plutonium bomb, and Victor Weisskopf who worked on the effects of the bomb. From their personal experience in both the problems of bomb development and the abilities of German science and industry, they were the best experts to judge the danger of a German bomb. That they believed themselves to be in a tight race with their former German colleagues is a strong indication that Germany would have been able to succeed.

After the war, when the gigantic size of Manhattan Project became known, it was deduced that "even with full support by the regime, the development of the bomb was unthinkable." As a consequence, "the moral issue, whether it was justified to build such a horrible weapon of mass destruction for Hitler, never arose." [5] While this judgement was justified for the uranium bomb, it was a misperception for the plutonium route, which had consumed only a third of the cost of the Manhattan Project. The investment of US\$ 600 million led to a capacity to build at least 40 plutonium bombs per year. The first plutonium bombs were produced at a cost of US $\$ 15$ million each. Even at a somewhat higher cost in Germany, the building of a number of plutonium bombs would have consumed only a small fraction of the 2 billion Reichs-Mark (RM) that were spent for the rocket project [6]. Due to the increasing impact of warfare, the building of a medium sized reactor for the generation of plutonium and a reprocessing plant for its separation would have had to start much earlier than the Manhattan project. An interesting aspect is that Germany had a great advantage over the USA in solving the most difficult problem of the plutonium bomb: The danger of pre-detonation from the spontaneous fission of $\mathrm{Pu} 240$, a side product of $\mathrm{Pu} 239$ generation during reactor operation. The resulting need for an extremely fast ignition can only be solved by hollow sphere implosion, a field in which German engineers had pioneered since 1930 [7]. Due to this technical advantage and the possibility of a much earlier start, there was a serious danger that the Third Reich would win the race for the plutonium bomb. On this basis, the question of why the German program failed has gained importance.

\section{The German Uranium Project}

The German Uranium Project was launched in April 1939 by the education ministry after it had been informed by several scientists about the newly discovered energy source capable of generating power and of creating extremely strong explosives. Immediately after the beginning of the war in September 1939, the Heereswaffenamt (HWA) assumed control of the Uranium Project. A special unit headed by the physicist Kurt Diebner was set up, thus creating the first military office for nuclear power in the world [8].

\subsection{The "Secret Research Reports" of the German Uranium Project}

The activities of the "Uranium Club" — as the group of less than 100 scientists was nick-named-are well documented. In 1944 and 1945, the special "ALSOS" unit of the US army seized German nuclear laboratories with the advancing front in order to confiscate materials, detain the scientists, and collect scientific documents. ALSOS' scientific head, the Dutch scientist Samuel Goudsmit, published the first book on the German Uranium Project based on first-hand information from interrogating the scientists and studying the documents [9]. After declassification, one set of the reports was returned to the Nuclear Research Center Karlsruhe as the main successor organization of the Uranium Project. As CEO of the center, the author gave these documents to Deutsches Museum at Munich in 1996.

\subsection{The Heereswaffenamt Report}

The most important document on the German Uranium Project, however, is the status report of the HWA [10], submitted in February 1942, describing the work during almost the first three years, a time span in which the Allies had been able to produce the first bomb. In early 1942, the deteriorated military situation called for a focusing of weapons development on projects promising short term results. In order to prepare a review conference of the 
Uranium Project, a secret report of 144 pages was written by Diebner and his co-workers. After a comprehensible "Introductory Survey" of 20 pages, the report describes the results of the project in scientific language on the basis of 137 scientific reports, which are listed in an annex to the report. While the ALSOS collection may be fragmentary due to some documents being possibly lost or destroyed, the report gives a complete account of the activities of the Uranium Project from a military perspective.

This important document was almost lost. While keeping the scientific reports as evidence of their work, the members of the Uranium Club must have destroyed the military report before the Allied troops arrived. ALSOS did not find a single copy. Only 40 years after the end of the war Walker discovered that Erich Bagge, a close collaborator of Diebner, had kept a copy. However, since Bagge's death in 1996, his document collection is missing. Fortunately, copies were kept at the archives of the city of Haigerloch. After 1990, a second original copy appeared in Moscow, seized by Russian soldiers during the invasion of Berlin. Since 2010, the only remaining original has been kept at the archives of the Max Planck Society (Figure 1). As this important, authentic, and contemporaneous document has not been easily accessible, it has until now not been sufficiently analyzed.

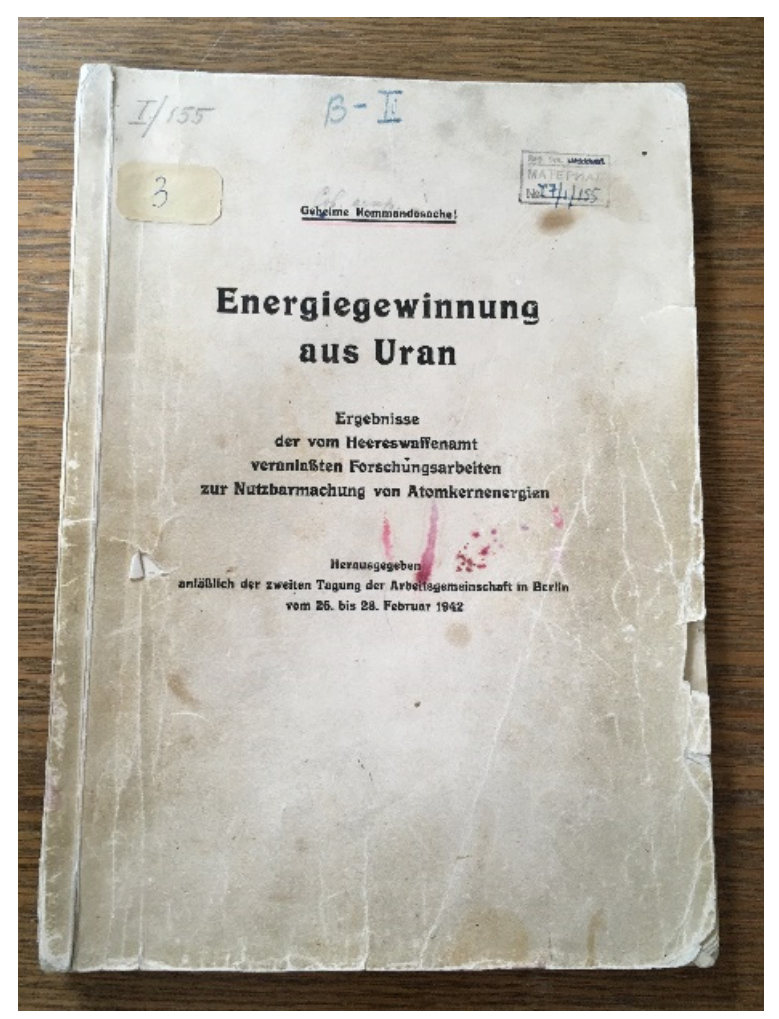

Figure 1. The only preserved original copy of the Heereswaffenamt (HWA) report.

In both copies, the first 5 pages containing title and preface had been cut out neatly. This has given rise to various speculations about who might have been named as authors of the report [11]. As the author knows from experience, official German governmental reports do not name authors. Such reports are compiled from contributions of the various experts by the head of the responsible desk (in this case Diebner) who also would have had to seek the agreement of the other departments of the HWA and further governmental agencies involved. According to the standard procedure, Diebner than had to obtain clearance from his superiors (from the head of the research department, Erich Schumann, up to the "Chef des HWA", General Emil Leeb), who may have introduced comments or changes. While Diebner certainly controlled the whole report, his superiors may have limited their interest to the more comprehensible introduction and closing remarks. 
Unnoticed until now, there is a considerable discrepancy within the report. The technical part is a matter-of-fact description of the rather limited achievements and abstains from raising expectations. Its brief chapter on "the possibility of explosives" speaks only about a temperature effect of the reactor, which "will become important for the judgement whether nuclear fission could lead to the production of highly charged explosives. [ ... ] One would need to enrich the isotope $U 235$ until the resonance absorption is quantitatively marginal and to choose at the same time very large amounts of moderator". This shows that the concept of the bomb is vague and corresponds to a power excursion in a reactor, similar to the explosion of the Chernobyl power plant.

Even more cautious is the paragraph on plutonium. By mid-1940, the German physicists had learned from their own theoretical work [12] and from a US-publication [13], that a power reactor, as a by-product of energy generation, would produce "Element 93" from neutron capture in U 238, which would be transformed to the fissionable "Element 94" (plutonium) by Beta-decay. From the Bohr-Wheeler theory, the Germans deduced that this new element would be a better alternative to $U 235$ as a fuel for a reactor and a bomb. However "Element 94 whose fate we do not yet know" is only briefly mentioned in an annex to chapter 2. "Its importance is that it could (in contrast to $\mathrm{U}^{235}$ ) be easily enriched by chemical means should it be produced in significant amounts. More precise statements [... ] will only be possible after start-up of the machine". The possibility that "Element 94" could open a much easier way to the bomb is not mentioned.

In considerable contrast, the introductory survey announces: "If the "chain reaction" runs slowly the uranium is a heat generating machine, if it runs fast, an explosive of highest efficiency". The brief paragraph on an explosive underlines that a uranium-bomb should contain at best very small amounts of the dominating isotope $U$ 238, which would be difficult to achieve, but that "today we know theoretically a second route to the production of an explosive, which, however, can only be tested when a heat generating machine is operating". Then follows the most often quoted sentence of the report: "As there are in any substance some free neutrons, it would suffice for the ignition of the explosive to unite a sufficient amount (presumable 10-100 kg). This announcement of the bomb's critical mass is the only technical statement without any corresponding explanation in the technical part of the HWA-report.

The technical part was certainly written by the responsible experts among Diebner's co-workers. While they used uniformly the notation " $\mathrm{U}^{235}$ ", the Introductory Survey and the Conclusions apply the opposite notation " $\mathrm{U}_{235}$ ", an indication of different authorship. The author of the comprehensible parts must have been Diebner, because his superior, Schumann, would have expressed a pessimistic view of the Uranium Project. While Diebner's co-workers reported the results correctly and unemotionally, Diebner obviously tried to defend his project by raising expectations of its potential and by embellishing the poor progress made. Diebner's euphemism had no success in history-the HWA withdrew from the Uranium Project—but a lasting effect on the historical narrative: All historians described the report in rare unanimity as "aggressively optimistic" (Powers) [14], "enthusiastic" (Walker) [15], "encourag[ing]" (Rose) [16], a "strong contrast to Schumann's skepticism" (Karlsch) [17], or "qualified optimist[ic]" (Cassidy) [18]. No one seems to have studied the main part of the report.

Many other important messages of the report have not been recognized by the former authors. The first surprise is the table of contents (Figure 2). In view of the different scientific and technical problems, one would expect separate chapters on reactor and bomb. However, there is no chapter on the bomb. Instead, the "possibility of an explosive" appears as a special case of a starting reactor (sub-chapter $5 \mathrm{c}$ ). 
$\underline{T} \underline{a} \underline{\mathrm{b}} \underline{\underline{l}} \underline{\mathrm{e}} \underline{\underline{o}} \underline{\mathrm{f}} \underline{\mathrm{C}} \underline{\mathrm{O}} \underline{\mathrm{n}} \underline{\mathrm{t}} \underline{\mathrm{e}} \underline{\mathrm{n}} \underline{\mathrm{t}} \underline{\mathrm{s}}$

r.

Introducing Survey

1. Evolution of the Problem

2. Mechanism of Eneróy Producino Systems

3. Experimental Investigation of Materials.

4. Production of the Necessary Materials

4. Production of the Necess
5. Future Development.......

10

10

14

Mechanism of Energy Producing systems

1. Nuclear Reactions in the Uranium Machine..

2. Loss of Neutrons in U-238.

3. Generation of Neutrons by Fissioning of U- 235

4. Possibility and Size of the U-Machine

a) The Homogenous Machine

b) Possibility of the Layer Machine

c) Size of the Layer Machine

5. Temperature of the Machine and Start-up Procedure ........ 37

a) Working Temperature

b) Start-up Process

c) Possibility of the Explosive

Annex: Improvement by Additional Processes

a) Fissioning of U-238

b) Production and Fissioning of Element 94

Summary

(b)

III.

Experimental Investigation of Materials

1. Properties of the Elementary Processes

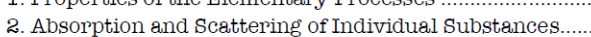

3. Model Experiments (Large-scale Tests)

Production of the Necessary Materials

1. The Separation of Isotopes with Special Regard to

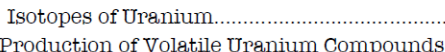

2. Tests of Production of Volatile Uranium Compounds

for Upanium Enrichment

Figure 2. Translated reproduction of the table of contents of the HWA-report (without the detailed structure of the chapters III. to V.).

The reason for this subordinate placement can be derived from a paragraph on the future development of the project (Figure 3).

\section{Future Development}

Today, the further development of the experimental work is determined by the pace of the material procurement. Once the necessary amounts of uranium metal and heavy water will be available the construction of a first self-sustaining machine will be tried out. This machine will be purely an experimental device. If it is successful - as to be expected after the laboratory experiments - there will be three tasks for further development:

1. The concrete design of the machine to a technically applicable device.

2. The technical, especially military application of the machine.

3. The production of a uranium explosive.

Figure 3. Translated reproduction of page 15/16 of the HWA report. 
This paragraph shows the fundamental difference in approaches of the USA and Germany. In the US, the Manhattan Project started in June 1942 long before the possibility to harvest the power of the nucleus by a chain reaction was demonstrated. In Germany, this proof of principle was a precondition for starting a larger program on a power reactor and bomb development. It has not been recognized so far that this condition means no less than that bomb development was at no time part of the Uranium Project because the German scientists did not master the proof of principle.

The brief technical chapter " $5 \mathrm{c}$ " on the possibility of explosives, which covers little more than one page, describes a run-away reaction of a reactor working with thermal (slow) neutrons in highly enriched U 235. This misconception of the principle of an atomic bomb is based on only two scientific reports.

The first quotation refers to half a page on a nuclear explosive, which Werner Heisenberg had inserted into a 52-page theory of the nuclear reactor, presented in two parts after joining the Uranium Club in December 1939 [19] and January 1940 [20]. Heisenberg had found out that a reactor could be made if the rare fissionable $U 235$ was slightly enriched. In this case, normal water would be good enough as a moderator to slow down the fast fission neutrons even though it absorbs neutrons. As long as one was restricted to using natural uranium, much larger quantities and a better moderator with less neutron absorption, like heavy water, must be used. His pioneering work became the basis of the German project and made him the accepted, yet informal, intellectual leader of the Uranium Club.

However, Heisenberg's cursory reactor theory contains several mistakes. He had rightly deduced that a rise in temperature will reduce the reactivity by Doppler broadening of the resonance absorption lines of $U$ 238. This effect exists indeed and contributes to the inherent safety of water-cooled reactors. But Heisenberg overestimated the Doppler effect when predicting that it would stabilize the reactor at a certain temperature, switching criticality on and off when cooling down and heating up the reactor. He overlooked that a reactor will stop after reaching criticality unless the fissioned $U 235$ nuclei are replaced and that, therefore, a reactor must contain a surplus of uranium. Its contribution to the reactivity must be compensated by a control system of neutron absorbing material.

Just this misconception is the starting point for Heisenberg's preliminary thinking about a possible explosive. As the stable temperature of a reactor would rise with the enrichment-level of $U$ 235, it would grow unlimited in case of pure $U 235$ because the regulating effect of resonance absorption in $\mathrm{U} 238$ disappears. Heisenberg's demand of pure $\mathrm{U} 235$ for a bomb is coincidentally correct although the concept-an exploding reactor-is wrong. Heisenberg had further deduced that one would need tens of kilograms if not more than a ton of pure $\mathrm{U} 235$ for a bomb, another accidently correct deduction from his misconception. Heisenberg considered it impossible to produce such large amounts of U 235. To boost the technology of mass spectroscopy over ten orders of magnitude or to develop a new isotope separation technology within a few years, both carried out in the Manhattan Project, would indeed have been impossible for Germany.

The other paper cited in the HWA report, the only one devoted to nuclear explosives in the overall history of the Uranium Club, was written by Paul O. Müller in May 1940 [21]. Müller, a bright doctoral student of Erwin Schrödinger at Graz University, had joined the Kaiser Wilhelm Institute for Physics immediately after the start of the Uranium Project in May 1939. He was the only supporter of national socialism among the nuclear physicists of the institute. That could be the reason why Heisenberg asked Müller to calculate the degree of enrichment needed for the explosion. In doing so, he gained a witness loyal to the party line for his conclusion that a uranium bomb was unattainable. Müller confirmed that the $U$ 235 content must be enriched by at least $70 \%$ and that a very large amount of moderator would be needed. Despite his interest in the bomb, Müller was drafted in October 1940 and killed in Russia in March 1942 [22].

The HWA does not mention any further work on a nuclear explosive between May 1940 and February 1942-another proof that there was no bomb development work in the Uranium Project. 
It may seem incredible that a brilliant scientist like Heisenberg had an incorrect understanding of the physics of the atomic bomb. However at that time, it was not only Heisenberg and Müller but all physicists who had focused their interest on thermal neutrons after the Italian physicist Enrico Fermi had discovered that nuclear reactions become more efficient the slower the neutrons are. The German physicists were not aware of the need to use fast neutrons to achieve much higher temperatures than in conventional bombs, as discovered by Otto Frisch and Rudolf Peierls in March 1940 [23]. That is confirmed by the listing of the neutron generating processes in the HWA report, omitting the fission of $U 235$ by fast neutrons (Figure 4).

The question whether a chain reaction will be possible can

only be answered on the basis of a complete accounting of

the neutrons. Neutron producing processes are:

1. the fissioning of U235 by thermal neutrons,

2. the fissioning of $\mathrm{U}^{238}$ by fast neutrons;

consuming processes are

1. the escape of neutrons

2. the resonance absorption in U238

3. the absorption in unavoidable impurities.

Figure 4. Translated reproduction of a part of page 20 of the HWA report.

Despite the consistent presentation of this incorrect bomb concept in the report, all historians believe that the critical mass of 10 to $100 \mathrm{~kg}$ mentioned in the introduction refers to a realistic bomb with fast neutrons simply because it is strikingly similar (although ten times more accurate) to the contemporaneous margin of the Manhattan Project (1-100 kg) [24]. However, they overlooked that the preceding text establishes again the context of a reaction with slow neutrons. In addition, such an accurate estimate of the critical mass would have required a detailed theory of the bomb and a precise measurement of the relevant cross sections. Both achievements would have been proudly reported by the HWA, but there is no trace of it. Sometimes it is even claimed that the margin may concern plutonium [25], but this is absurd because the German scientists never produced even a microgram of plutonium and had no data that could have been used in a calculation. Finally, it went unnoticed that the sentence, which was considered to be proof of sufficient knowledge of bomb physics, refers in fact to a malfunction of the bomb. The described unplanned ignition of a critical mass by a stray neutron leads to a "fizzle" [26]. The bomb merely dismantles itself and the precious material may fall into the hands of the enemy. To ensure a reasonable yield by an appropriate ignition process is one of the most difficult problems of bomb development.

A plausible explanation for the "10-100 kg" statement can be found in a letter of Heisenberg's co-worker Karl Wirtz defending a patent application. He claimed that a plate of U 235 measuring one square meter with a few millimeter thickness, covered by paraffin, would produce either heating for a long time or an extremely powerful explosion [27]. Such a plate would have a mass of $10-100 \mathrm{~kg}$. Wirtz' official letter written on behalf of the Kaiser Wilhelm Institute for Physics-certainly in agreement with Diebner as its acting director-reveals that, in the superficial understanding of the German physicists, reactor and bomb may even have the same shape.

The agreement between the critical mass of Wirtz' plate using thermal neutrons and the US critical mass of a bomb with fast neutrons is just another coincidence. The many amazing coincidences have helped to create the erroneous impression that the German scientists did know the correct principles of the bomb.

In June 1942, the Uranium Project was back in the responsibility of the research council and Diebner was replaced by Abraham Esau as a coordinator and by Heisenberg as director of the Kaiser Wilhelm Institute for Physics. At the same time, the new minister 
for armament, Albert Speer, became interested in the project because, at that point in the war, only a "wonder-weapon" could restore the former supremacy of the "Wehrmacht". However the German physicists had not been able to demonstrate the possibility of using nuclear power and could not give any indication of an ability to develop an atomic bomb. When Speer offered additional funding, expecting a demand of several million RM, the apparently intimidated von Weizsäcker asked for only 40,000 RM. The poor progress of the Uranium Project and the feeble presentation by the scientists led Speer to conclude that an atomic bomb was not possible during the remaining time of the war. Instead, he gave the green light and funding to the rocket development program, but supported a moderate scientific program on nuclear physics until the end of the war [28].

\subsection{The Farm Hall Transcripts}

The Farm Hall transcripts are a unique and independent source of information about the Uranium Club. From July 1945 to January 1946, ten of its most important members had been detained in a British land house where all their discussions were recorded. British officers produced transcriptions in English, partly literal and partly summarizing, which were published in 1992. It is a very rare situation that today we can witness the reaction of the German scientists when they learned about the destruction of Hiroshima by an atomic bomb.

In the hours after being informed about the bombing, Heisenberg tried to understand how the bomb might have worked and to calculate the critical mass. In the way he did it, Hans Bethe and Edward Teller, the best nuclear weapon physicists of their time, recognized the typical mistakes of a beginner. They were convinced that he never had thought about the problem before $[29,30]$. The reader is invited to view a video by Teller, in which he expresses his pride in the fact that the great Heisenberg had made the same mistakes that he had made [31]. The American physicist Jonothan Logan deduced from the recordings, that "there never had been any knowledge" about bomb physics in the Uranium Club [32]. Jeremy Bernstein came to the same conclusion in his enlightening commentary to the Farm Hall transcripts [33]. Landsman observed that Heisenberg "had only a tentative understanding of the physics and technology of nuclear weapons" [2].

The well founded publications of these highly competent physicists were never recognized by historians and have had no impact on the prevailing historical narrative.

\subsection{Significant Omissions in the Uranium Project}

What the documents do not contain is another important source of information for a scientist. Even if there was no order to work on a nuclear explosive, some scientists may have used their relative freedom to study bomb physics either for curiosity or to endear themselves to the regime.

If the German physicists, as some historians believe [34], knew about the need to employ fast neutrons in a bomb it would have been necessary to measure the cross-sections for fast neutron fissioning of $\mathrm{U} 235$ and $\mathrm{Pu} 239$ in order to determine the amount of material needed. Otto Hahn knew the pioneering work on U 235 in the USA well, because his former assistant A.V. Grosse had participated [35]. Following this approach, Lise Meitner's successor at his institute, Josef Mattauch, could have produced micrograms of pure U 235. He was the world's leading specialist in isotope separation by mass spectrometry but he used his excellent equipment only for the determination of the exact masses of fission products [36]. Regarding plutonium, Hahn, who had worked for years on trans-uranium elements together with Lise Meitner, could have been the first to isolate plutonium. Instead, he tried only to separate "Element 93", a much more difficult task because of its short half-life compared to the long-living "Element 94" [37]. Samples of U 235 and Pu 239 could have been investigated with fast neutrons generated in a cyclotron.

Cyclotrons had begun in 1939 to replace the simple high voltage facilities as the main work horse of nuclear physics. A total of 14 cyclotrons were in operation; nine in the USA, two in both in England and in Japan, and one in Denmark. While an additional 
27 were under construction worldwide only one cyclotron was being built in Germany. It took six years before operation started at Heidelberg in autumn 1944 [38]. A second cyclotron project at Leipzig has filled a thick file of documents between April 1937 and June 1944 without ever advancing beyond the stage of paperwork [39]. Two cyclotrons became available in occupied countries. The cyclotron at Paris was operated by Bothe's assistant Wolfgang Gentner, independent of the Uranium Project, in cooperation with Ferdinand Joliot [40]. The most modern cyclotron with $5 \mathrm{MeV}$ deuterons in Denmark would have been ideal to produce $2 \mathrm{MeV}$ neutrons in order to study the fission cross section of $\mathrm{U} 235$ and $\mathrm{Pu} 239$, but several attempts to transport it to Berlin or to seize Bohr's institute in Denmark were obstructed by Heisenberg [14]. Most unreasonable was his declining of an offer by Speer "to exercise all his powers in order to build equally large or even bigger cyclotrons as in the USA", because of lack of experience. Several younger members of the Uranium Club had international experience with cyclotrons, in particular Wolfgang Gentner, who had worked with the most modern cyclotron at Berkeley University and had helped Joliot with the final construction of the Paris accelerator. The tool to study plutonium was systematically impeded by Heisenberg.

But the German physicists could have known the fission cross section of $U 235$ for fast neutrons from another experiment. The Vienna group of the Uranium Club specialized on the measurement of fast neutron cross sections while being restricted to use natural uranium and natural neutron sources. The main interest was to determine the contribution of the fissioning of $U 238$ by fast neutrons to the neutron balance in a reactor. For their fifth report they applied medium fast neutrons (200-900 keV) in order to study the absorption in $U 238$ in this energy range, in which $U 238$ cannot be fissioned. Therefore, the observed fission neutrons must have come from the rare $\mathrm{U} 235$. The measured cross section of $3.7 \mathrm{barn}$ could have been considered as an approximation of the value for $2 \mathrm{MeV}$-neutrons. However, the report attributes no importance to this side-result [41]. Only Heisenberg recognized the significance of this measurement and remembered it when trying to understand the Hiroshima bomb at Farm Hall [42]. If the German physicists were at all interested in the physics of the bomb, the measurement would have been a sensation: The fact that their value is three times larger as the real one (1.2 barn) would have meant that a mass of only $2 \mathrm{~kg}$ would suffice for a U 235 bomb.

\subsection{A Hidden New Insight about the Possible Bomb}

While preparing his introductory lecture at the February 1942 conference [43], Heisenberg must have discovered the need to use fast neutrons for an explosive. It is interesting to observe how he both published and hid this new insight at the same time. He showed a figure (Figure 5, "Abb. 1") but he did not explain its meaning. He also separated the figures from the manuscript, which ends with a handwritten note that the diapositives were already at the HWA. This sentence also appears in the edition of his complete works. Apparently, Heisenberg wanted to leave proof of his correct knowledge in the files of the HWA while not making it widely known within the Uranium Club. The author has found the page with the three pictures erroneously attached to von Weizsäcker's report about "Element 93" at the Archives of Deutsches Museum. When Irving had found a copy of this sheet in 1966, Heisenberg was "delighted that you discovered the transparencies" in a letter, confirming that it belongs to his lecture [44].

Heisenberg's strategy was successful: When Gerlach had to respond in November 1944 to a question regarding nuclear weapons he insisted that "a stormy propagation of neutrons" can only be achieved with several tons of material [45]. The reactor bomb concept was still in force. 


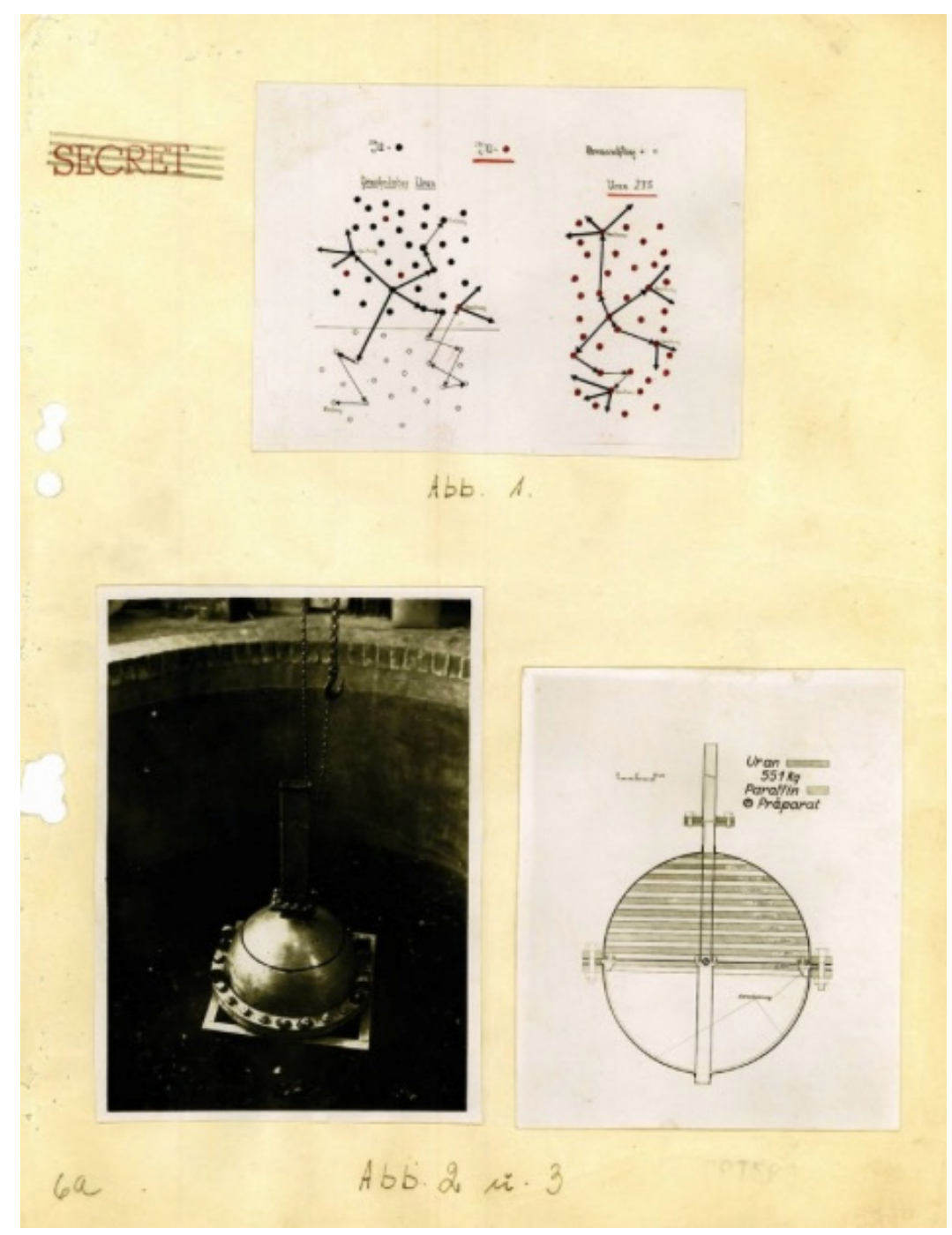

Figure 5. The sheet with the figures Heisenberg showed during his lecture at the HWA conference. "Abb. 1" shows fissions by moderated neutrons in a reactor (left) and by fast neutrons in pure U 235 (right). “Abb. 2 u. 3" depict experiment B 3.

\section{Why the German Uranium Project Failed}

Demonstrating the chain reaction-the precondition for a large program on reactor and bomb development in the Uranium Project-is not a complicated task. One only needs to stack large quantities of graphite and insert uranium rods or bricks. Less intelligent geometry can be compensated by more material. To control the system, one needs neutron monitoring equipment and-if not misled by Heisenberg's self-control theory-built-in rods of neutron-absorbing material, which can be used to approach criticality safely and to tune the system to a continuous operation at almost zero power.

Half a year after the beginning of the Manhattan Project, Fermi succeeded at the first attempt. With material cost of one million US\$ [46], the "Chicago pile" was still done in an academic style, with small scientific groups working out the physics of the reactor as well as the measurement technique for neutrons. Students were hired for the construction work.

There must have been a special reason that a country like Germany, with its high level in science and industry, was not capable of meeting this goal by more than five years.

\subsection{A Missed Opportunity of Early Success}

A promising opportunity for early success was a project belonging to the physicalchemist Paul Harteck, successor to the famous Otto Stern at Hamburg who had to leave 
Germany in 1933. In spring 1940, Harteck got 15 tons of carbon dioxide ice from the chemical industry. A very cold moderator would have been ideal for a zero-power experiment. A recent calculation by the Israeli reactor physicist Ron Dagan shows that 12-15 tons of uranium oxide (one cubic meter) would have been sufficient to reach criticality. Harteck urged his colleagues to lend him all available uranium, but the response was lukewarm. Due to their own demands, Heisenberg and Diebner sent only a total of $185 \mathrm{~kg}$ [47], each equating to the volume of a soccer ball. The procurement of the necessary amount should have been no problem, at least for a second experiment several months later.

Long after the war, Heisenberg admitted that he obstructed Harteck's experiment in order to avoid an early success: "It was too extravagant for a first experiment to use fifty tons of material and to do the whole program at once." [48].

\subsection{A Dubious Decision with Serious Consequences}

The most important decision at the beginning of a nuclear program restricted to the use of natural uranium was the choice between carbon and heavy water as a moderator. Carbon must be employed in great quantities but was an established industrial product. Heavy water, contained in natural water by only $0.014 \%$, is a much better moderator but requires fastidious isotope separation. In the USA, Fermi chose carbon for the first generation of experiments and reactors, and postponed the use of heavy water ("too expensive") [49] for the second generation of more compact reactors.

In Germany, the opposite decision in favor of heavy water was taken in early 1940 under dubious circumstances. There was no technology available in Germany to produce heavy water. The only provider was Norway, occupied since April 1940. There was no exact basis for an economic comparison of the two alternatives but it was evident that any process involving isotope separation is more expensive by orders of magnitude than a chemical production. Wirtz has reported that heavy water was "as expensive as gold" [50] (at that time $1.1 \mathrm{\$} / \mathrm{g}$ ) [51], while graphite was available at few dollars per kilogram [52].

Heisenberg had stated that pure carbon may not be suitable and recommended more detailed calculations for improved arrangements of fuel and moderator [20]. A special problem was that normal coal contains traces of elements, in particular boron, which absorb neutrons strongly. When Walther Bothe, an excellent physicist (he won the 1954 Nobel prize), measured the neutron absorption of graphite, he investigated the influence of impurities but his result surpassed today's correct value and Heisenberg's estimate by a factor of two [53]. Heisenberg excluded the use of carbon without further calculations and blamed Bothe for having "ruled out" carbon [48]. While Irving followed Heisenberg's interpretation [47], Walker derived from the HWA report-regardless that it was written two years later-that carbon was considered suitable after further investigations but ruled out for economic reasons [25]. However, the report states something different: Even if the absorption may be smaller as measured by Bothe, carbon would not be suited because it would be impossible to produce cleaner coal [10].

But the statements of Heisenberg and the HWA are wrong. Unnoticed by the historians, important facts were disregarded: The calculations recommended by Heisenberg had had been done by von Weizsäcker's doctoral student Karl-Heinz Höcker. His result meant that Bothe's value would not rule out carbon as a moderator if larger quantities were employed. He added a calculation of a carbon moderated reactor "because coal is a material, which is certainly available much easier than heavy water" [54]. Reassessing Bothe's measurement in 1980, the reactor physicist Lothar Köster came to the same conclusion [55]. He could not comment Höcker's report because at that time the secret reports were not yet made available. In addition, the main provider of graphite in Germany had not been asked whether it would be possible to produce much cleaner material. Only after the war did the company confirm that it would not have been a problem [56]. All these strange facts cast doubt on the seriousness of Heisenberg's and Diebner's decision in favor of heavy water unless one assumes that both, and perhaps also Bothe, had used again an opportunity to avoid an early breakthrough of the Uranium Project. If that was their intention, it was 
extremely successful: As an immediate consequence, Harteck, although considering it a mistake, did not repeat his experiment with larger quantities. The whole program suffered a delay of almost three years until larger amounts of heavy water were delivered. The unique opportunity of a success two years ahead of Fermi was ruined and the danger of Hitler's bomb was eliminated once and forever.

The choice of a liquid moderator had another disadvantage: The need of a vessel made of a special material with low neutron absorption. Its manufacture was costly and delivery times were long. If it turned out during the experiment that the amounts of uranium and moderator needed had been underestimated, which was often the case, there was no way to enlarge the setup. When the same happened to Fermi, he simply mounted layer after layer of graphite and uranium until he eventually reached criticality.

\subsection{The Reactor Experiments}

Three groups competed to demonstrate a self-sustaining chain reaction in natural uranium (Table 1). Two groups employed Heisenberg's sandwich structures with alternating layers of uranium and moderator (paraffin until heavy water became available) in a ball shaped vessel. The Berlin group headed by Wirtz employed flat plates of uranium (for example in experiment B3 (Figure 5, Nr. 2, and 3)), while the Leipzig group, headed by Robert Döpel, used concentric hemispheres. Diebner was competing with the Uranium Club at the HWA facilities at Gottow. He invented a system of entangled uranium cubes in a cylindrical vessel containing the moderator.

Table 1. The 20 reactor experiments after Harteck's first test.

\begin{tabular}{|c|c|c|c|}
\hline Year & Berlin/Haigerloch & Leipzig & Gottow/Stadtilm \\
\hline 1940 & B1 uranium oxide/paraffin & L1 uranium oxide/paraffin & \\
\hline 1941 & B2 uranium oxide/paraffin & L2 $142 \mathrm{~kg} \mathrm{U} / 164 \mathrm{~kg} \mathrm{D} \mathrm{D}_{2} \mathrm{O}$ & G1 uranium oxide/Paraffin \\
\hline \multirow[t]{3}{*}{1942} & B3 $551 \mathrm{~kg} \mathrm{U} / 44 \mathrm{~kg}$ paraffin & $\mathrm{L} 3$ uranium metal $/ 1501 \mathrm{D}_{2} \mathrm{O}$ & \\
\hline & B4 $740 \mathrm{~kg} \mathrm{U} / 37 \mathrm{~kg}$ paraffin & L4 $755 \mathrm{~kg} \mathrm{U} / 164 \mathrm{~kg} \mathrm{D} \mathrm{D}_{2} \mathrm{O}$ & \\
\hline & B5 $864 \mathrm{~kg} \mathrm{U} / 8 \mathrm{~kg}$ paraffin & & G2a $200 \mathrm{~kg} \mathrm{U}, 2201 \mathrm{D}_{2} \mathrm{O}$-ice \\
\hline 1943 & B6a-d 0.9-2.2 t U/1.5 t D $2 \mathrm{O}$ & & $\begin{array}{c}\mathrm{G} 2 \mathrm{~b} 200 \mathrm{~kg} \mathrm{U}, 2201 \mathrm{D}_{2} \mathrm{O} \text {-ice } \\
\text { G3a } 540 \mathrm{~kg} \mathrm{U} / 5251 \mathrm{D}_{2} \mathrm{O}\end{array}$ \\
\hline 1944 & B7 2.2 t U/1.5 t D $2 \mathrm{O}$ & & G3b $540 \mathrm{~kg} \mathrm{U} / 5251 \mathrm{D}_{2} \mathrm{O}$ \\
\hline 1945 & $\begin{array}{c}\mathrm{B} 81.5 \mathrm{t} \mathrm{U} / 1.5 \mathrm{t} \mathrm{D}_{2} \mathrm{O} / 10 \mathrm{t} \\
\text { graphite }\end{array}$ & & $\mathrm{G} 4(?)$ \\
\hline
\end{tabular}

The first experiments with paraffin did not show any effects. After heavy water became available, an increase of the neutron flux was observed - at first in L4-but remained dependent on the inserted neutron source in all further experiments. The Leipzig tests were more promising than those at Berlin but had to be stopped when the set-up was destroyed by the burning down of the uranium metal. Although Diebner's design proved soon to be more promising, Heisenberg stuck to plates until 1944. Only when the move of the Kaiser Wilhelm Institutes from Berlin into the south-western region of Germany signaled the near end of the war, did he change to the cubes invented by Diebner and admitted that carbon was a better moderator as assumed earlier [57]. Experiment B8 at Haigerloch (Figure 6) was equipped with a thick graphite reflector immediately around the heavy water vessel acting as a reflector but also as a moderator. The experiment could have been successful if the uranium cubes of the HWA would have been inserted into the graphite [58]. 


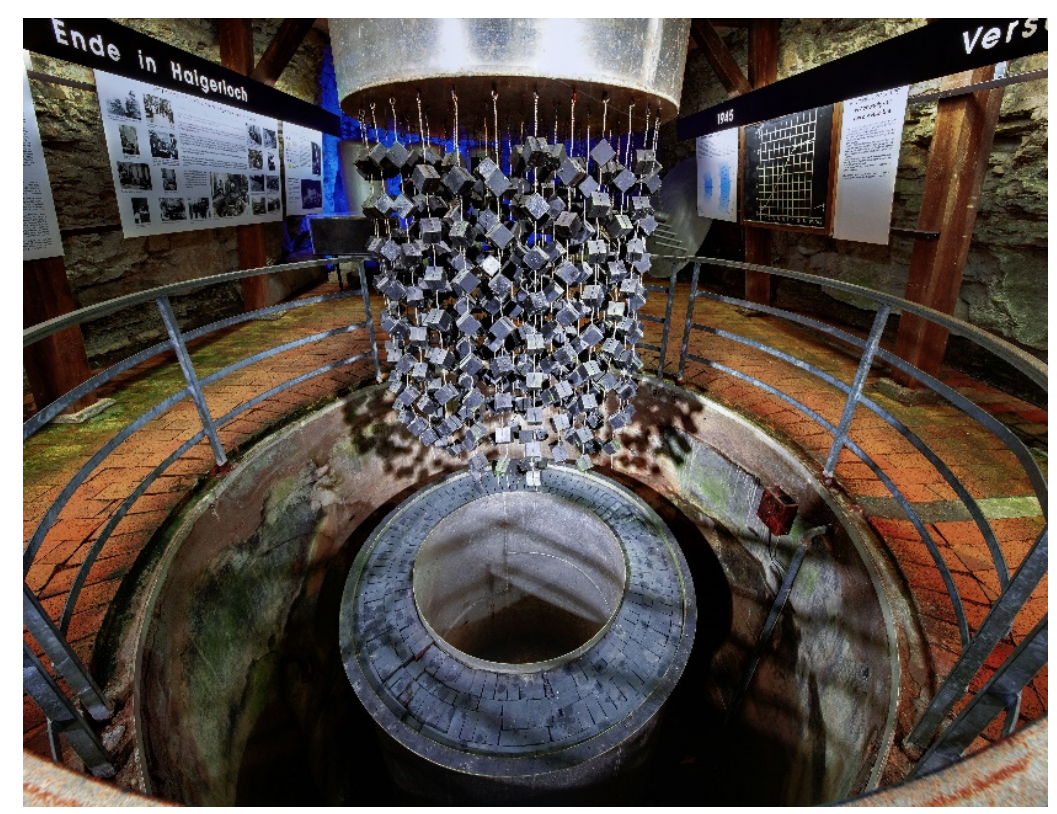

Figure 6. Reconstruction of the last experiment at Haigerloch.

None of the historians who have described the work of the Uranium Club has recognized the absurdity of the experiments. One after the other failed-21 times over five years-for consistently the same reason: The shortage of material. In view of the production facilities in Germany and in occupied Czechia and a large stock of uranium seized during the invasion of Belgium [47], the shortage of uranium is without any reason. Heisenberg criticized the HWA: "There was no good reason to give the Auer factory an order for only one half-ton of uranium when it could as well have been for twenty tons" [48], but only after the war. The delivery of heavy water from Norway was a constant bottleneck and ceased after bombing in 1943 but nothing was undertaken to improve the supply [59].

However, even with these restrictions there was a simple way to achieve the main goal of the project: A joint experiment combining all available material. But Heisenberg and Diebner never planned - and never were forced - to combine their resources. What prevented the HWA from sending soldiers and lorries to the Kaiser Wilhelm Institute to carry the uranium and heavy water to the HWA laboratories? Normally, the regime was not known for walking on eggshells to achieve its goals.

The conclusion that a success was intentionally avoided is also supported by some otherwise irresponsible features of all German reactor experiments. The absence of control rods in the reactors for a safe approach to criticality and the non-existence of any precaution against radiation when the set-up would have to be dismantled, as shown by Figure 5 (Abb. 2) and Figure 6, were only reasonable if criticality was not expected.

A further confirmation is a remarkable statement by Abraham Esau who coordinated the Uranium Project before and after Diebner. According to two independent reports he warned the members of the Uranium Club not to trigger a large military program. If after two years there would have been no bomb, they would lose their lives [14,47].

\subsection{A Half-Hearted Project under Weak Leadership}

Diebner's regime began with a defeat. He had confiscated the newly built Kaiser Wilhelm Institute at Berlin in order to turn it into the central nuclear research centre but the scientists working outside Berlin refused to leave their institutes and Diebner had to give in. Without support from his superiors at the HWA, and not being a professor, his influence on the members of the Uranium Club was limited. As a result, the activities were spread over more than a dozen universities and three Kaiser Wilhelm Institutes all over Germany, with major contributions coming from Berlin, Hamburg, Leipzig, Heidelberg, Munich, and Vienna [10]. 
Instead of intervening with the work of the Uranium Club, Diebner concentrated on his own work at the HWA facilities at Gottow. As he and his co-workers were much more oriented towards practical questions than the members of the Uranium Club, he had a reasonable chance to win the internal race. In the report for the review conference in February 1942, the HWA's own work was left aside. Hence, it was not affected when the HWA decided to withdraw from the Uranium Project.

Over six years, groups at Berlin, Hamburg, Leipzig, and the HWA laboratories worked on reactor experiments, others on uranium enrichment, and still other groups measured nuclear data. Such a broad approach is reasonable when entering an entirely new field of science, but from his experience as a science manager, the author finds it strange that the progress of the groups was not monitored regularly in order to focus, step-by-step, the limited resources on the most promising solution. Nothing like this happened even once in the six years. As long as there was no strong pressure to produce results, competition was better than cooperation.

It was the fear created by a totalitarian regime that discouraged the German scientists. The modest academic Uranium Project was the best that could have happened to them. Difficult times laid behind. Scarcity of funds since the first world war had weakened experimental physics. A huge intellectual loss was the result of the anti-Jewish legislation of 1933, expelling 1000 professors from their positions. Theoretical physics was particularly affected by the loss of every second professor. Thanks to the Uranium Project, the physicists had better research funds than in the decades before. They enjoyed great freedom in choosing their research subjects. In his long career as a science manager, the author has hardly ever met a scientist who was content with his working conditions. Every progress report ends normally with demands for more personnel, greater financial resources, better equipment, and larger laboratories. With one exception (Harteck), nothing of this can be found in the documents. Nobody wanted to create problems.

\subsection{Heisenberg's Role}

At the meeting of the Uranium Club in September 1939, it had been decided to ask Heisenberg to join and contribute a report on the possibility of using nuclear power in the next meeting. After only a few weeks of work, Heisenberg presented an impressive reactor theory in 56 pages on December 1939 and January 1940. From then on, he was the intellectual leader of the Uranium Club although officially he had no special role. As he was clearly the most renowned physicist, his leadership was accepted if not expected by the members of the Uranium Club. It was his role to introduce meetings with decision makers. Questions were always directed to him. According to a special decree of the Wehrmacht, Heisenberg could not be drafted to military service without the agreement of the Kaiser Wilhelm society [58]. Seemingly, he indeed played the role his former colleagues in the USA had expected.

It is a mystery that Heisenberg was still in Germany. The year 1933 had brought the turning point in Werner Heisenberg's steep scientific career when he received the Nobelprize for his work on quantum mechanics. The assumption of power by the Nazis affected his life more than any other non-Jewish German physicist. To this day, Heisenberg's international reputation is overshadowed by the allegation that he worked on atomic weapons for Hitler.

When all German-Jewish professors were expelled from their positions, Heisenberg was one of the disgracefully few non-Jewish colleagues who wanted to protest by resigning from his professorship at Leipzig. However Max Planck advised him to stay on and build "islands of permanence" in order to save as much of German physics and as many German physicists as possible during the foreseeable catastrophe [59]. Heisenberg conceded but his opposition to the new regime became the obstacle to his dream to inherit the chair of theoretical physics at Munich, belonging to his teacher Arnold Sommerfeld. An attack in the SS-journal "Das schwarze Corps" called Heisenberg "a white Jew" meaning an "Arian" German infected by "the destructive Jewish spirit" who would "need to be fought twice as 
urgently as racial Jews" [60]. This put him in mortal danger of immediate imprisonment in a concentration camp. He could have easily saved himself by leaving Germany but he stayed and preferred a dangerous fight for his reputation. At his request, SS-leader Himmler ordered a thorough investigation of Heisenberg's political attitudes, which lasted a whole year. When interrogated at the infamous SS-headquarters, he was treated correctly but signs on the walls "breath calmly and deeply" showed that normally other measures were applied. This experience had a strong impact on Heisenberg [18]. After one year, Himmler put an end to the allegations because "we cannot afford to lose or kill this man" [61]. In summer 1939, in the wake of the forthcoming war, Heisenberg was offered a professorship by Columbia University at New York [18]. However, again he decided to stay in Germany. His wife regretted that "he decided against his family, against their security" [62]. He must have felt a higher responsibility for German physics than for his young family.

Heisenberg was not the motor of the Uranium Project. That he never acknowledged the rather drastic mistakes he had made in his reactor theory can only mean that he never tried to improve it. Otherwise the brilliant physicist must have stumbled over his errors.

Heisenberg's letters to his wife exhibit clearly how boring the project was to him [63]. His real interest is reflected by a series of articles he wrote about the S-matrix and the theory of elementary particles [64-66]. He organized a conference about cosmic rays and edited the results [67]. He also wrote a philosophical publication on "Die Ordnung der Wirklichkeit" (Reality and its Order) [68,69], to which he must have given much thought. He spent time traveling to give lectures [18], on gardening, and on rehearsing and performing on the piano [63].

When Heisenberg was asked after the war whether a demonstration of a sustainable chain reaction would have taken the project out of his hands he responded: "This was one of the main points we discussed especially among a small group including Weizsäcker, Wirtz and myself. We felt that it was very important [that] these things must remain in our hands, then we could always keep control of what goes on. That we did achieve." [48]. And indeed, if one assumes that Heisenberg wanted to avoid a large military program by delaying the Uranium Project, all his strange behavior and his many "mistakes" suddenly appear rational: The fact that his theory gave too small values for uranium and moderator but was never improved, the staged rivalry with Diebner in order to forestall a joint experiment, the preference for uranium plates despite the experimental evidence in favor of Diebner's cubes, the use of Bothe's measurement without further calculations to rule out carbon, the refusal to support Harteck's dry ice experiment, the exaggeration of the difficulties of bomb development without improving his superficial and erroneous understanding, the hiding of his insight that only fast neutrons could be used for a bomb, and his demonstrated lack of interest and his dampening of expectations in all his presentations. A special case was his obstruction of all plans to equip the Uranium Club with cyclotrons, which would have allowed to study the properties of "Element 94". Although several cyclotrons would have been mandatory if German nuclear physics was to keep up with the international standard, he never supported the Heidelberg construction and the Leipzig planning and declined the offer by Speer to build large cyclotrons with a feeble argument. He also discouraged plans to bring the cyclotron from occupied Copenhagen to Berlin or to seize Bohr's institute several times.

How naïve it was to believe that a scientist could control the fruits of his work is shown by the history of the Manhattan Project. After the first bomb had been tested successfully in July 1945, the scientists who advocated a peaceful demonstration of the new weapon had to realize that they had lost any influence on the employment of the bombs [8]. Heisenberg's equally naïve strategy of controlling the Uranium Project, however, succeeded due to the special circumstances: The missing support from high level representatives of the regime-Speer came in too late-let the officials act cautiously without a real commitment to the project. Not all members of the Uranium Club were content with the way Heisenberg exerted his influence, in particular Harteck, the most ambitious member, who complained "How can you be a leader in such technological matters when you have never run an 
experiment in your life? That's ridiculous! That's no excuse whatsoever!". But the rare opportunities for meetings and the political mistrust among them prohibited any uproar. The majority of the members were happy if left alone in doing their research. A breakthrough in the reactor experiments would have destroyed the idyll.

After the war, Heisenberg did not admit his technical mistakes. He might not have imagined that all the secret documents, the HWA-report, and recordings of Farm Hall would become available later. However, he never denied his destructive strategy based on his mantra that a bomb development program would weaken the military strength of Germany and that even the USA "would have won the war against Germany earlier if [they] had made no atomic bombs." Therefore, delaying the program, omitting any theoretical work on the physics of the bomb, and obstructing measurements of the necessary data was no sabotage, "We had to avoid being committed to make a big effort making atomic bombs. What we wanted was to get enough money to go on with our reactor project, but no more than that." [48]. He chose his wording carefully when he mentioned a possible explosive in his frequent introductory talks, like in the review conference of February 1942: "The pure isotope U 235 constitutes without doubt an explosive of unimaginable force. However, this explosive is very difficult to get" or, even more cautious, before Speer in June 1942: "From the positive results up to now it seems not to be excluded that after production of a uranium burner [ ... ] one can get to explosives, which surpass all present ones a million times in effectiveness."

After the war, Heisenberg admitted that he had overestimated the necessary technical effort [59]. The fact that he never claimed to have prevented atomic bombs in Hitler's hands on moral grounds could have been for reasons of self-protection only. At Farm Hall, Gerlach had warned the detained scientists: "When we get back to Germany we [ ... ] will be looked upon as the ones who have sabotaged everything. We won't remain live long there". To prevent accusation of sabotage, they formulated a joint memorandum on their activities in the Uranium Project, saying that "it did not appear feasible at the time to produce a bomb with the technical possibilities available in Germany" [33]. Gerlach's warning was not unfounded, it took longer than Heisenberg's life until active resistance against the Nazi-regime was recognized as justified and legal in the Federal Republic of Germany. It was prudent not to confess to have prevented the "wonder-weapon" that could have changed the outcome of the war. And one must consider that Heisenberg was a fervent patriot and did not want to appear responsible for Germany's defeat.

Was his mantra that a bomb development program would have been harmful to Germany's military strength his real conviction or just a protective claim against possible accuses? It is sufficient to explain his actions and omissions. But it could as well have been a pretext for an ethically motivated refusal for building the atomic bomb, in particular, for Hitler's regime. This cannot be proven, but, equally, not excluded.

\section{Conclusions}

Contrary to the prevailing opinion, Nazi-Germany could have produced a number of atomic bombs earlier than the USA with much less effort than used for the rocket program. However, Heisenberg and the other members of the Uranium Club did not work on nuclear weapons during World War II. They had no order to do it and they did not work voluntarily on the atomic bomb. Heisenberg had convinced himself that a bomb development program would be harmful to Germany's military strength. Therefore, he thought-or pretendedthat avoiding a bomb program was his patriotic duty. By manifold actions and omissions Heisenberg - in tacit agreement with the project coordinators-avoided any theoretical work on bomb physics and delayed the possible success of the work on an experimental reactor because a proof of the possibility of harvesting nuclear energy would have triggered a large military program. In the end, he could have been deeply satisfied with a reverse of the regime's slogan: We made "use of warfare for physics" [48]. 


\section{About the Author}

I am a nuclear physicist and have done basic research at Bonn University and at the Weizmann Institute of Science in Israel. From 1976 until 1987, I was the director of the nuclear energy program of the Federal Republic of Germany, thus, in a way, a successor to Esau, Diebner, and Gerlach. Within this time, I was the German representative at and a co-chairman of the INFCE-conference for the evaluation of the connections of civil and military nuclear technologies. From 1991 to 2006, I was CEO of the Karlsruhe nuclear research center. In recent years I have studied the work of German physicists on nuclear power during World War II after I realized that my knowledge of physics, of civil and military nuclear technologies, and of science management can help to correct the many misinterpretations and misunderstandings governing the current historical narrative.

Funding: This research received no external funding.

Data Availability Statement: All data are available in publicly accessible repositories.

Acknowledgments: I am grateful to Konrad Kleinknecht and Dan Gabriel Cacuci for encouraging this publication. My thanks for a helpful exchange of arguments go to Kurt Scharnberg who has also provided detailed Information about Harteck's experiment and to Ron Dagan for a critical review of the paper and for performing the criticality analysis for Harteck's setup. Furthermore, I thank Ron Jones for his mindful help in editing this article. I enjoyed valuable support of the Archives of the Max Planck-society and by Egidius Fechter of Atomkellermeuseum Haigerloch.

Conflicts of Interest: The author declare no conflict of interest.

\section{References and Notes}

1. Einstein, A. Letter to President F.D. Roosevelt of August 2nd. 1939. Available online: https://www.osti.gov/opennet/manhattanproject-history /Events/1939-1942/ einstein_letter.html (accessed on 4 October 2020).

2. Landsman, N.P. Getting even with Heisenberg. Stud. Hist. Philos. Modern Phys. 2002, 33, 297-325.

3. Popp, M. Misinterpretations and Ignored Physical Facts: The History of "Hitler's Bomb" Needs to Be Corrected. Ber. Wissenschaftsgesch. 2016, 39, 265-282. [CrossRef] [PubMed]

4. Walker, M. Nuclear Weapons and Reactor Research at the Kaiser Wilhelm Institute for Physics. In The Kaiser Wilhelm Society under National Socialism; Heim, S., Sachse, C., Walker, M., Eds.; Cambridge University Press: Cambridge, UK, 2009 ; p. 369.

5. Bedürftig, F. Als Hitler Die Atombombe Baute_Lügen und Irrtümer über das Dritte Reich; Piper: Munich, Germany, 2004; pp. 34-38.

6. Tooze, A. Ökonomie der Zerstörung. Die Geschichte der Wirtschaft im Nationalsozialismus; Bundeszentrale für politische Bildung: Bonn, Germany, 2007; p. 709.

7. Popp, M. Werner Heisenberg und das Deutsche Uranprojekt im Dritten Reich. In Quanten 6; Kleinknecht, K., Ed.; Hirzel: Stuttgart, Germany, 2018; pp. 11-12.

8. Jungk, R. Heller als Tausend Sonnen; Bertelsmann Lesering: Scherz, Switzerland, 1956; pp. 94-97.

9. Goudsmit, S.A. ALSOS, 2nd ed.; Tomash Publishers: Los Angeles, CA, USA, 1968.

10. Heereswaffenamt. Energiegewinnung aus Uran, Ergebnisse der vom Heereswaffenamt Veranlaßten Forschungsarbeiten zur Nutzbarmachung von Atomkernenergien, Herausgegeben Anlässlich der Zweiten Tagung der Arbeitsgemeinschaft vom 26. Bis 28. Februar 1942 in Berlin; AMPG-I-34-105; Archiv der MPG: Berlin, Germany, 1942.

11. Cassidy, D. Uncertainty; Freeman: New York, NY, USA, 1992; p. 443.

12. Von Weizsäcker, C.-F. Eine Möglichkeit der Energiegewinnung aus U 238; AMPG I-34-120; Archiv der MPG: Berlin, Germany, 1940.

13. McMillan, E.; Abelson, P.H. Radioactive Element 93. Phys. Rev. 1940, 57, 1185-1186. [CrossRef]

14. Powers, T. Heisenbergs Krieg; Hoffmann und Campe: Hamburg, Germany, 1993.

15. Walker, M. German National Socialism and the Quest for Nuclear Power; Cambridge University Press: Cambridge, UK, 1989 ; p. 48.

16. Rose, P.L. Heisenberg and the Nazi Atomic Bomb Project; University of California Press: Berkeley, CA, USA, 1998 ; p. 174.

17. Karlsch, R. Hitlers Bombe; DVA: Munich, Germany, 2005; p. 86.

18. Cassidy, D.C. Beyond Uncertainty; Bellevue Literary Press: New York, NY, USA, 2009.

19. Heisenberg, W. Die Möglichkeit der technischen Energiegewinnung aus der Uranspaltung. In Original Scientific Papers/Wissenschaftliche Originalarbeiten; Deutsches Museum Archiv, FA-002-461; Springer: Berlin/Heidelberg, Germany, 1989; pp. 378-396.

20. Heisenberg, W. Bericht über die Möglichkeit der technischen Energiegewinnung aus der Uranspaltung (II). In Original Scientific Papers/Wissenschaftliche Originalarbeiten; Deutsches Museum Archiv, FA-002-474; Springer: Berlin/Heidelberg, Germany, 1989.

21. Müller, P.O. Eine Bedingung für die Verwendbarkeit von Uran als Sprengstoff, Deutsches Museum Archiv, FA-002-482.

22. Kernbauer, A.; Popp, M. Paul Otto Müller, Schrödingers Talentierter Schüler; Publikationen aus dem Archiv der Universität Graz, Band 50; Akademische Druck und Verlagsanstalt: Graz, Austria, 2020. 
23. Frisch, O. What Little I Remember, 2nd ed.; Cambridge University Press: Cambridge, UK, 1999; p. 126.

24. DeWolf Smyth, H. Atomic Energy for Military Purposes, 2nd ed.; Princeton University Press: Princeton, NJ, USA, $1945 ;$ pp. 2-23.

25. Walker, M. Nazi Science-Myth, Truth, and the German Atomic Bomb; Perseus: Cambridge, MA, USA, 1995.

26. Reed, B.C. The Science of the Manhattan Project, 3rd ed.; Springer: Berlin/Heidelberg, Germany, 2015; p. 85.

27. Wirtz, K. Letter to Reichspatentamt of 11.03.1941; AMPG-I-34-73/4; Archiv der MPG: Berlin, Germany, 1941.

28. Speer, A. Erinnerungen; Propyläen: Berlin, Germany, 1969; pp. 241-242.

29. Bethe, H. The German Uranium Project. Phys. Today 2000, 54, 34-36. [CrossRef]

30. Teller, E. Heisenberg hat die Atombombe sabotiert. In Heisenberg, Hitler und die Bombe; Schaaf, M., Ed.; Diepholz: Berlin, Germany, 2001; p. 114.

31. Teller, E. Heisenberg, Bohr and the Atomic Bomb (34/147). Available online: https://www.youtube.com/watch?v=ClhLnZtgcsE (accessed on 19 November 2020).

32. Logan, J. The Critical Mass. Am. Sci. 1976, 84, 263-277.

33. Bernstein, J. Hitler's Uranium Club-The Secret Recordings at Farm Hall, 2nd ed.; Copernicus: New York, NY, USA, 2001 ; p. 185.

34. Walker, M. Physics, History and the German Atomic Bomb. Ber. Wissenschaftsgesch. 2017, 40, 271-288. [CrossRef] [PubMed]

35. Nier, A.O.; Booth, E.T.; Dunning, J.R.; Grosse, A.V. Further Experiments on Fission of Separated Uranium Isotopes. Phys. Rev. 1940, 57, 748. [CrossRef]

36. Mattauch, J. Collection of reports; AMPG 11; Archiv der MPG: Berlin, Germany, 1939-1945.

37. Hahn, O.; Straßmann, F. Zur Frage nach der Entstehung des 2,3 Tage-Isotops des Elementes 93 aus Uran, Deutsches Museum Archiv, FA-002-735.

38. Max-Planck-Institut für Kernphysik. Von Kernphysik und Kosmochemie zu Quantendynamik und Astroteilchenphysik; Max-PlanckInstitut für Kernphysik: Heidelberg, Germany, 2008; p. 2.

39. Documents on the planned Leipzig Cyclotron, Archiv der MPG: Berlin, Germany, AMPG I-34-80.

40. Hoffmann, U.; Schmidt-Rohr, U. Wolfgang Gentner_Festschrift zum 100. Geburtstag; Springer: Berlin/Heidelberg, Germany, 2006.

41. Jentschke, W.; Lintner, K. Schnelle Neutronen in Uran (V), Deutsches Museum Archiv, FA-002-637.

42. Heisenberg, W. Letter to David Irving of June 10, 1966; Archiv der MPG: Berlin, Germany, AMPG III-093-1743 01 088.

43. Heisenberg, W. Die theoretischen Grundlagen für die Energiegewinnung aus der Uranspaltung, Deutsches Museum Archiv, FA-002-761.

44. Heisenberg, W. Letter to David Irving of July 6, 1966; Archiv der MPG: Berlin, Germany, AMPG III-093-1743 01 061.

45. Gerlach, W. Letter to Prof. Mentzel of 18.11.1944, reproduced in Goudsmit. In ALSOS, 2nd ed.; p. 180.

46. Atomic Heritage Foundation. Chicago Pile-1. Available online: https://www.atomicheritage.org/history/chicago-pile-1 (accessed on 11 July 2019).

47. Irving, D. Der Traum von der deutschen Atombombe; Mohn: Gütersloh, Germany, 1977.

48. Ermenc, J. Atomic Bomb Scientists Memoirs; Meckler: London, UK, 1989.

49. Dahl, P.F. Heavy Water and the Wartime Race for Nuclear Energy; Institute of Physics: Bristol, UK, $1999 ;$ p. 173.

50. Wirtz, K. Im Umkreis der Physik; Kernforschungszentrum Karlsruhe: Karlsruhe, Germany, 1987.

51. Historical Gold Prices. Available online: https:/ / onlygold.com/gold-prices/historical-gold-prices / (accessed on 12 February 2020).

52. Atomic Heritage Foundation. Fermi on Chicago Pile-1. Available online: https://www.atomicheritage.org/key-documents/ fermi-chicago-pile-1 (accessed on 21 May 2020).

53. Bothe, W.; Jensen, P. Die Absorption thermischer Neutronen in Kohlenstoff. Zeitschrift Physik 1944, 124, 749-755. [CrossRef]

54. Höcker, K.-H. Berechnung der Energieerzeugung in der Uranmaschine. II Kohle als Bremssubstanz, Deutsches Museum Archiv, FA002-477.

55. Köster, L. Zum unvollendeten ersten deutschen Kernreaktor 1942/1944. Naturwissenschaften 1980, 67, 573-575. [CrossRef]

56. Höhne, E. Letter to Werner Heisenberg of 9.9.1947, quoted after Müller, W.D. In Geschichte der Kernenergie in der Bundesrepublik Deutschland; Schäffer: Stuttgart, Germany, 1990; p. 569.

57. Beckurts, K.-H. Kernenergie in Deutschland—Bilanz und Perspektiven-Festvortrag aus Anlaß des 75. Geburtstages von Prof. Karl Wirtz. KfK-Nachrichten 1985, 17, 102.

58. Oberkommando der Wehrmacht, Decree of September 19, AMPG-34/173/6; Archiv der MPG: Berlin, Germany, 1942.

59. Heisenberg, W. Der Teil und das Ganze; Piper: Munich, Germany, 1969.

60. “Weiße Juden" in der Wissenschaft. Available online: https://uni-tuebingen.de/fileadmin/Uni_Tuebingen/Fakultaeten/ MathePhysik/Institute/IAP/Forschung/MOettel/Geburt_QM/stark_weisse_juden_1937.html (accessed on 9 January 2021).

61. Himmler, H. Letter of July 21, 1938 to SS-Gruppenführer Heydrich, Goudsmit. In ALSOS, 2nd ed.; p. 116.

62. Heisenberg, E. Das Politische Leben eines Unpolitischen; Piper: München, Germany, 1980; pp. 79-80.

63. Hirsch-Heisenberg, A.M. (Ed.) Werner Heisenberg, Elisabeth Heisenberg-Meine liebe Li_Der Briefwechsel 1937-1946; Residenz: St. Pölten, Austria, 2011.

64. Heisenberg, W. Die beobachtbaren Größen in der Theorie der Elementarteilchen. Teil 1 Zeitschrift fur Physik 1943, 120, 513-538. [CrossRef]

65. Heisenberg, W. Die beobachtbaren Größen in der Theorie der Elementarteilchen. Teil 2 Zeitschrift fur Physik 1943, 120, 673-702. [CrossRef] 
66. Heisenberg, W. Die beobachtbaren Größen in der Theorie der Elementarteilchen. Teil 3 Zeitschrift fur Physik 1944, 123, 93-112. [CrossRef]

67. Heisenberg, W. (Ed.) Vorträge über kosmische Strahlung; Springer: Berlin/Heidelberg, Germany, 1943.

68. Heisenberg, W. Die Ordnung der Wirklichkeit; Piper: Munich, Germany, 1984; pp. 217-230.

69. Heisenberg, W. Reality and Its Order; Kleinknecht, K., Ed.; Springer: Cham, Switzerland, 2019. 